\title{
AGROSAINSTEK
}

Jurnal Ilmu dan Teknologi Pertanian

Website jurnal : http://journal.ubb.ac.id/index.php/agrosainstek

Artikel Penelitian

\section{Hasil dan Komponen Hasil Kedelai (Glycine max L. Merr) yang Diberi Pemupukan Nitrogen Lanjutan pada Fase Reproduktif (R1)}

\section{Yield and Yield Components of Soybean (Glycine max L.) with Supplementary Nitrogen Fertilization on Reproductive Phase (R1)}

\author{
Helmi Salim¹, Sosiawan Nusifera ${ }^{1 *}$, Nyimas Myrna Elsa Fathia ${ }^{1}$ \\ ${ }^{1}$ Fakultas Pertanian Universitas Jambi, Kampus Pinang Masak, Jln. Raya Jambi-Ma. Bulian KM. 15, \\ Mendalo Jambi
}

Diterima : 16 Maret 2016/Disetujui : 11 Agustus 2016

\begin{abstract}
This research aim to determine the effect of continued nitrogen fertilization to reproductive phase on yield and yield components of soybean. The experiment conducted in teaching and research farm, Faculty of Agriculture, University of Jambi from April to September 2014. The experiment arranged in factorial randomized block design with two replications. First factor were four soybean varieties and second factor were dosages of continued nitrogen fertilization consist of $0 \mathrm{~kg} \mathrm{ha}^{-1}(\mathrm{n} 0), 40 \mathrm{~kg} \mathrm{ha}^{-1}(\mathrm{n1}), 50 \mathrm{~kg} \mathrm{ha}^{-1}$ (n2) and $60 \mathrm{~kg} \mathrm{ha}^{-1}$. Measured variables orbserved were length of reproductive phase, number of pods per plant, number of filled pods, weight of 100 seeds, and weight of seed per plant. The result showed that nitrogen did not have effect on evaluated varieties. There were differences in length of reproductive phase, number of pods per plant, number of filled pods, and weight of 100 seeds among soybean varieties. The second nitrogen fertilization with different dosages gave significant effect in number of pods per plant, number of filled pods and weight of seed per plant. Four varieties had same yield potential if developed around research area, but to get larger seed size, Anjasmoro variety was highly recommended. The best dosage to increase yield between varieties was n2 (50 kg N ha-1).
\end{abstract}

Key word : Soybean, Fertilization, Nitrogen, Reproductive

\begin{abstract}
ABSTRAK
Penelitian ini bertujuan mengetahui pengaruh pemupukan nitrogen lanjutan pada fase reproduktif pada hasil dan komponen hasil kedelai. Percobaan akan dilakukan di Kebun Percobaan (teaching dan research farm) Fakultas Pertanian Universitas Jambi mulai bulan April 2014 sampai dengan September 2014. Percobaan disusun dalam rancangan acak kelompok pola faktorial dengan dua ulangan. Faktor pertama adalah empat varietas kedelai dan faktor kedua adalah dosis pemupukan nitrogen lanjutan yang terdiri atas $0 \mathrm{~kg}$ Nitrogen(n0), $40 \mathrm{~kg} \mathrm{ha}^{-1}(\mathrm{n} 1), 50 \mathrm{~kg} \mathrm{ha}^{-1}$ (n2), dan $60 \mathrm{~kg} \mathrm{ha}^{-1}$. Variabel yang diamati adalah panjang fase reproduktif, jumlah polong per tanaman, jumlah polong berisi, bobot 100 biji, bobot dan biji per tanaman. Hasil memperlihatkan bahwa tidak terdapat perbedaan pengaruh nitrogen pada tiap-tiap varietas yang dievaluasi. Terdapat perbedaan panjang fase reproduktif, jumlah polong total per tanaman, jumlah polong berisi per tanaman, dan bobot 100 biji diantara varietas kedelai. Pada sisi lain, pemupukan nitrogen kedua berbeda dosis memberikan pengaruh yang nyata pada variabel jumlah polong total per tanaman, jumlah polong berisi per tanaman, dan bobot biji per tanaman. Keempat varietas memiliki potensi hasil yang sama jika dikembangkan diwilayah sekitar wilayah penelitian. Namun jika ingin mendapatkan ukuran biji yang lebih besar, varietas anjasmoro sangat direkomendasikan. Dosis terbaik yang dapat meningkatkan hasil antar varietas adalah n2 (50 $\left.\mathrm{kg} \mathrm{N} \mathrm{ha}^{-1}\right)$.
\end{abstract}




\section{Pendahuluan}

Dalam persiapan menghadapi era otonomi daerah, berbagai upaya untuk mengidentifikasi komoditas-komoditas unggulan dan prospektif semakin intensif dilakukan oleh pemerintah daerah Jambi. Hal ini penting untuk mengukur kesiapan Jambi menghadapi berbagai tantangan dalam era globalisasi dan pasar bebas. Pengembangan berbagai komoditas unggulan di Jambi yang pada umumnya terdiri dari tanaman-tanaman tahunan tidak bisa begitu saja mengabaikan pengembangan usaha peningkatan produksi pangan. Pengembangan komoditas-komoditas seperti padi, kedelai, dan jagung saat ini menjadi perhatian utama pemerintah pusat yang telah tersosialisasi ke seluruh provinsi di wilayah Republik Indonesia (Gema Palagung).

Kedelai merupakan salah satu tanaman pangan penghasil protein nabati yang sangat penting. Tingginya kandungan protein kedelai (pada kultivar-kultivar unggul mencapai $30-40 \%$ ) (Puslitbangtan, 1993), menjadikan makananmakanan hasil olahan kedelai sebagai konsumsi utama untuk memenuhi kebutuhan protein keluarga. Dengan semakin beragamnya jenis-jenis makanan baru yang menggunakan bahan utama kedelai memberikan isyarat bahwa kedelai mempunyai nilai ekonomi sosial yang tinggi dan peranannya semakin strategis dalam kehidupan manusia. Permintaan kedelai akan terus meningkat sejalan dengan pertumbuhan jumlah penduduk, membaiknya pendapatan per kapita, meningkatnya kesadaran masyarakat akan kecukupan gizi, dan berkembangnya berbagai industri pakan ternak. Konsekuensinya, permintaan kedelai kian meningkat tiap tahunnya. Sayangnya peningkatan permintaan ini tidak dapat diimbangi dengan peningkatan produksi, sehingga kita masih harus terus mengimpor dari negara-negara produsen.

Produksi kedelai di Provinsi Jambi belum mampu memenuhi kebutuhan kedelai untuk konsumsi perkapita per tahun. Menurut Dinas Pertanian Tanaman Pangan Tingkat Provinsi Jambi (2001) produksi kedelai untuk tahun 2000 baru mencapai 4. 233 ton dengan rata-rata hasil 0.98 ton ha $^{-1}$. Produksi ini hanya mampu menyediakan kedelai untuk konsumsi per kapita per tahun sebesar $0.7 \mathrm{~kg}$, sementara menurut Rukmana dan Yuniarsih (1995), dengan mengacu kepada standar Pola Pangan Harapan (PPH) yang dianjurkan oleh FAO, konsumsi bahan kacang-kacangan terutama kedelai pada tahun 2000 idealnya adalah $13.1 \mathrm{~kg}$ per tahun per kapita.

\footnotetext{
*Korespondensi Penulis.

E-mail: sosiawan_nusifera@yahoo.com (S. Nusifera)
}

Sebagai upaya mengatasi masalah kekurangan ini, usaha peningkatan produksi yang mencakup ekstensifikasi dan intensifikasi mutlak dilakukan karena untuk tetap mengimpor bukanlah hal yang bijaksana. Usaha-usaha peningkatan melalui intensifikasi merupakan prioritas dalam meningkatkan produksi kedelai mengingat ekstensifikasi semakin sulit direalisasikan akibat semakin sempitnya lahan-lahan produktif pertanian.

Penggunaan kultivar unggul dalam intensifikasi pertanian sudah merupakan hal yang tidak bisa ditawar lagi dalam sistem pertanian modern. Namun demikian, hasil kedelai di provinsi Jambi yang hanya 0,98 ton ha-1 belum merefleksikan keunggulan kultivar tersebut karena masih jauh dari potensi hasil rata-rata yang berkisar antara 1.7 - 2.0 ton ha-1. Hal ini menunjukkan masih kurangnya informasi dan pengetahuan petani tentang teknologi budidaya tanaman terutama yang menyangkut ketepatan penggunaan kultivar dari segi lingkungannya dan berbagai aspek budidaya tanaman lainnya seperti pemupukan.

Pemupukan sebagai alternatif utama untuk menjamin ketersediaan hara bagi tanaman, memerlukan teknik dan metode tertentu sesuai dengan jenis tanah, jenis tanaman, dan jenis pupuk itu sendiri. Berbagai aspek dalam pemupukan seperti dosis aplikasi, jenis pupuk, waktu aplikasi, dan efisiensi pemupukan, sangat penting untuk diperhatikan agar tujuan pemupukan tercapai (Whitney et al., 1985).

Rendahnya produktivitas kedelai erat sekali hubungannya dengan tingkat keguguran bunga yang sangat tinggi pada kedelai. Karakter-karakter seperti kandungan klorofil, periode pengisian polong, dan tingkat keguguran memiliki hubungan yang erat dengan fotosintesis. Sebagaimana tanaman legum pada umumnya, kedelai memiliki kekhususan tersendiri yaitu kemampuannya dalam menambat nitrogen dari udara bebas melalui aktivitas bakteri nodula akar (Rukmana dan Yuniarsih, 1995). Akan tetapi hubungan simbiosis antara kedelai dan bakteri Bradyrhizobium hanya berlangsung efektif hingga tanaman memasuki fase pembentukan polong. Untuk memenuhi kebutuhan nitrogen tanaman pada fase-fase tersebut, diperlukan pemupukan lanjutan dengan dosis tertentu guna memperlambat proses senesens dini daun dan degradasi klorofil sehingga kapasitas fotosintesis bisa dipertahankan. Namun demikian, pada tanaman kedelai pemupukan kedua cukup mengandung risiko sehubungan dengan bunga yang mudah gugur. Selain itu, secara teknis terdapat kesulitan akibat kanopi pada fase lanjut yang semakin rapat. Oleh karena itu, diperlukan teknik aplikasi pupuk yang dapat mengatasi hambatan 
tersebut. Di antara berbagai teknik aplikasi pemupukan yang telah dikenal secara luas, pemupukan melalui daun (foliar aplication) merupakan teknik aplikasi yang paling dianggap mampu mengatasi kendala dalam melakukan pemupukan terutama pada saat tanaman mulai memasuki fase reproduktif. Meskipun efisiensi pemupukan melalui daun dapat dikatakan rendah, teknik ini dapat menghindari risiko gugurnya daun akibat proses pemupukan langsung lewat tanah.

Selain teknik aplikasi, faktor lainnya yang menentukan efektivitas pemupukan adalah dosis pupuk. Kelebihan dan kekurangan dapat memiliki dampak negatif terhadap pertumbuhan tanaman. Oleh karena itu, perlu untuk diteliti dosis pemupukan optimum nitrogen yang diaplikasikan lewat daun yang memberikan hasil maksimum pada tanaman kedelai.

\section{Bahan dan Metode}

Percobaan dilakukan di Teaching and Research Farm Fakultas Pertanian Unja, mulai dari bulan April 2014 dan selesai pada bulan September 2014. Percobaan disusun dalam Rancangan Acak Kelompok pola factorial dua factor yang diulang dua kali. Perlakuan pertama adalah varietas yang terdiri atas empat taraf yaitu 'Anjasmoro', 'Wilis', 'Gema', dan Dering 1'. Faktor kedua adalah pemupukan nitrogen ke dua yang terdiri atas empat taraf yaitu $0,40 \mathrm{~kg}, 50 \mathrm{~kg}$, dan $60 \mathrm{~kg}$. Variabel yang diamati yaitu panjang fase reproduktif, jumlah polong per tanaman, jumlah polong berisi, bobot biji per tanaman, dan bobot 100 biji. Data dianalisis dengan menggunakan analisis varians dalam RAK. Jika terdapat pengaruh perlakuan, pengujian dilanjutkan dengan uji beda dua rata-rata dengan menggunakan Uji BNT pada taraf alpha $5 \%$.

\section{Hasil}

Hasil memperlihatkan bahwa tidak terdapat pengaruh interaksi antara varietas dan pemupukan kedua nitrogen pada seluruh variable yang diamati. Pengaruh mandiri varietas terlihat pada variable panjang fase reproduktif, jumlah polong per tanaman, jumlah polong berisi per tanaman, dan bobot 100 biji. Sedangkan pemupukan nitrogen kedua secara mandiri berpengaruh pada jumlah polong per tanaman, jumlah polong berisi, dan bobot biji per tanaman.

Analisis masing-masing pengaruh perlakuan tersaji pada Tabel 1, 2,3, 4, dan 5. Tabel 1 menunjukkan bahwa varietas Anjasmoro memiliki fase reproduktif yang lebih panjang dibandingkan dengan varietas lain, diikuti dengan varietas Wilis dan varietas Dering 1, sedangkan varietas Gema memiliki fase reproduktif lebih rendah dibandingkan varietas lain yaitu 49,8 hari.

Tabel 1. Panjang Fase Reproduktif Tanaman Kedelai Menurut Varietas dan Nitrogen.

\begin{tabular}{|c|c|c|c|c|c|}
\hline \multirow{2}{*}{ Varietas } & \multicolumn{4}{|c|}{ Dosis Pupuk Nitrogen } & \multirow{2}{*}{$\begin{array}{c}\text { Pengaruh } \\
\text { utama } \\
\text { Varietas }\end{array}$} \\
\hline & $\mathbf{n}_{\mathbf{0}}$ & $\mathbf{n}_{1}$ & $\mathbf{n}_{2}$ & $\mathbf{n}_{3}$ & \\
\hline Anjasmoro & 61 & 61 & 61 & 61 & $61 \mathrm{~A}$ \\
\hline Wilis & 57 & 57 & 57 & 57 & $57 \mathrm{~B}$ \\
\hline Gema & 50 & 50 & 49.5 & 50 & $49.8 \mathrm{D}$ \\
\hline Dering 1 & 54.5 & 55 & 55 & 54 & $54.6 \mathrm{C}$ \\
\hline Rata-rata & $55.6 \mathrm{a}$ & $55.7 \mathrm{a}$ & $55.6 \mathrm{a}$ & $55.5 \mathrm{a}$ & \\
\hline Keterangan: & \multicolumn{5}{|c|}{$\begin{array}{l}\text { Angka-angka yang diikuti oleh huruf besar } \\
\text { yang sama arah vertikal dan angka yang } \\
\text { diikuti oleh huruf kecil yang sama arah } \\
\text { horizontal berbeda tidak nyata menurut Uji } \\
\text { BNT pada taraf } \alpha=0.05\end{array}$} \\
\hline
\end{tabular}

Tabel 2 memperlihatkan bahwa jumlah polong total per tanaman tidak berbeda antara varietas Anjasmoro dan Gema. Kedua varietas ini memperlihatkan jumlah polong yang lebih banyak dibandingkan dua varietas lainnya. Sedangkan jumlah polong per tanaman pada varietas Wilis juga tidak berbeda dengan Dering 1.

Pada sisi lain, pemberian pupuk $\mathrm{N}$ berpengaruh nyata namun tidak terjadi peningkatan ketika dosis pemberian ditingkatkan lagi. Selanjutnya Tabel 3 memperlihatkan bahwa Jumlah polong berisi paling banyak terlihat pada varietas wilis sedangkan yang paling sedikit adalah Varietas Anjasmoro. Sedangkan dosis pupuk nitrogen yang menghasilkan polong berisi paling banyak adalah adalah dosis $50 \mathrm{~kg}$ per hektar. Meskipun demikian pemberian nitrogen dengan dosis $50 \mathrm{~kg}$ per hektar tidak berbeda nyata dengan dosis $40 \mathrm{~kg}$ per hektar.

Tabel 4 memperlihatkan bahwa pemberian perlakuan pemupukan nitrogen ke dua dengan dosis meningkat mulai dosis $40 \mathrm{~kg}$ per hektar sampai dengan $50 \mathrm{~kg}$ per hektar memperlihatkan bobot biji tanaman yang meningkat pula. Namun, penambahan nitrogen hingga dosis $60 \mathrm{~kg}$ justru malah menurunkan bobot biji per tanaman. Tabel 5 menunjukkan bahwa varietas yang menghasilkan rata-rata bobot 100 biji tertinggi adalah varietas Anjasmoro diikuti varietas Gema, varietas Wilis, sedangkan varietas Dering 1 menghasilkan ratarata bobot 100 biji paling rendah yaitu $13.1 \mathrm{gr}$. 
Tabel 2. Jumlah Polong Total Tanaman Kedelai

\begin{tabular}{|c|c|c|c|c|c|c|}
\hline \multirow{2}{*}{ Varietas } & \multicolumn{4}{|c|}{ Dosis Nitrogen(Kg N ha-1) } & \multirow{2}{*}{\multicolumn{2}{|c|}{ Rata-rata }} \\
\hline & 0 & 40 & 50 & 60 & & \\
\hline \multicolumn{7}{|l|}{ Anjasmor } \\
\hline o & 100.3 & 109.2 & 128 & 133.2 & 117.675 & $\mathrm{~A}$ \\
\hline Wilis & 143.6 & 198.5 & 183.1 & 173.8 & 174.75 & $\mathrm{~B}$ \\
\hline Gema & 120.9 & 137.8 & 141.1 & 136 & 133.95 & $\mathrm{~A}$ \\
\hline Dering 1 & 135.5 & 167.2 & 166.7 & 189.6 & 164.75 & $\mathrm{~B}$ \\
\hline & & & & & 147.7812 & \\
\hline Rata-rata & 125.075 & a $\quad 153.175$ & 154.725 & b $\quad 158.15$ & 5 & \\
\hline
\end{tabular}

Tabel 3. Jumlah Polong Berisi Tanaman Kedelai Menurut Varietas dan Nitrogen

\begin{tabular}{|c|c|c|c|c|c|c|c|c|c|c|}
\hline \multirow{2}{*}{ Varietas } & \multicolumn{7}{|c|}{ Dosis Nitrogen (Kg N ha-1) } & \multirow{2}{*}{\multicolumn{3}{|c|}{ Rata-rata }} \\
\hline & 0 & & 40 & & 50 & & 60 & & & \\
\hline Anjasmoro & 52.3 & & 74.2 & & 75.3 & & 70.6 & & 68.1 & $\mathrm{~A}$ \\
\hline Wilis & 86.2 & & 119.2 & & 146.7 & & 82 & & 108.525 & $\mathrm{C}$ \\
\hline Gema & 62.4 & & 82.3 & & 101.9 & & 98.6 & & 86.3 & $\mathrm{~B}$ \\
\hline Dering 1 & 98 & & 89.9 & & 94.7 & & 103 & & 96.4 & $\mathrm{BC}$ \\
\hline Rata-rata & 74.725 & $\mathrm{a}$ & 91.4 & $\mathrm{~b}$ & 104.65 & $\mathrm{~b}$ & 88.55 & $\mathrm{ab}$ & 89.83125 & \\
\hline
\end{tabular}

Tabel 4. Bobot Biji Tanaman Kedelai Menurut Varietas dan Nitrogen

\begin{tabular}{|c|c|c|c|c|c|c|c|}
\hline \multirow{2}{*}{ Varietas } & \multicolumn{4}{|c|}{ Dosis Nitrogen (Kg N ha-1) } & & \multirow{2}{*}{\multicolumn{2}{|c|}{ Rata-rata }} \\
\hline & 0 & 40 & 50 & 60 & & & \\
\hline Anjasmoro & 15.42 & 16.61 & 22.24 & 16.71 & & 17.76 & A \\
\hline Wilis & 12.85 & 20.56 & 28.68 & 15.22 & & 19.33 & A \\
\hline Gema & 10.56 & 14.52 & 20.63 & 21.4 & & 16.78 & A \\
\hline Dering 1 & 16.24 & 19.68 & 19.89 & 21.75 & & 19.39 & A \\
\hline Rata-rata & 13.77 & 17.85 & 22.86 & 18.77 & $\mathrm{~b}$ & 18.31 & \\
\hline
\end{tabular}

Keterangan:Angka-angka yang diikuti oleh huruf besar yang sama arah vertikal dan angka yang diikuti oleh huruf kecil yang sama arah horizontal berbeda tidak nyata menurut Uji BNT pada taraf $\alpha=0.05$

Tabel 5. Hasil Uji Pembandingan Nilai Rata-rata Bobot 100 biji

\begin{tabular}{lrl}
\hline Varietas & Bobot $100 \mathrm{biji}$ & \\
\hline Anjasmoro & 17.4 & $\mathrm{a}$ \\
Wilis & 13.3 & $\mathrm{bc}$ \\
Gema & 13.8 & $\mathrm{~b}$ \\
Dering I & 13.1 & $\mathrm{c}$ \\
\hline
\end{tabular}

Keterangan: rata-rata yg diikuti oleh huruf yang sama tidak berbeda nyata menurut uji Mann Whitney

\section{Pembahasan}

Varietas memegang peranan penting dalam perkembangan penanaman kedelai karena untuk mencapai produktivitas yang tinggi sangat ditentukan oleh potensi daya hasil dari varietas unggul yang ditanam. Potensi hasil biji di lapangan dipengaruhi oleh interaksi antara faktor genetik varietas dengan kondisi lingkungan tumbuh. Bila pengelolaan lingkungan tumbuh tidak dilakukan dengan baik, potensi daya hasil biji yang tinggi dari varietas unggul tersebut tidak dapat tercapai (Irwan, 2006).

Variabel pengamatan yang secara nyata dipengaruhi oleh factor Varietas adalah lama fase reproduktif, jumlah polong total per tanaman, jumlah polong berisi dan bobot 100 biji. Panjang fase reproduktif (Tabel 2), varietas Anjasmoro memiliki fase reproduktif yang lebih panjang 
dibandingkan dengan varietas Wilis, Dering 1 yaitu 61 hari, sedangkan varietas Gema memiliki fase reproduktif lebih rendah dibandingkan varietas lain yaitu 49.8 hari. Panjang fase reproduktif yang berbeda pada dasarnya mengindikasikan berbedanya periode pengisian polong. Periode pengisian polong yang lebih panjang boleh jadi berhubungan dengan banyaknya asimilat yang terakumulasi pada biji yang pada akhirnya menjadi penentu bobot ataupun ukuran biji. Meskipun variasi pengaruh varietas pada lama fase reproduktif tidak sejalan dengan bobot biji pada tiap-tiap varietas, variasi panjang fase reproduktif sejalan dengan bobot 100 biji atau ukuran biji. Varietas dengan fase reproduktif yang lebih panjang memiliki ukuran biji yang lebih besar dibandingkan varietas lainnya.

Variasi variable jumlah polong total pada varietas kedelai tampaknya tidak juga sejalan dengan bobot biji per tanaman yang memang sama. Hal ini nampaknya sangat erat terkait dengan variasi variable-variabel komponen hasil yang tidak sama. Varietas yang menghasilkan jumlah polong total tanaman tertinggi adalah varietas Wilis yaitu 174.75 polong, diikuti varietas Dering 1164.75 polong dan varietas Gema 133.9 polong sedangkan varietas Anjasmoro menghasilkan jumlah polong total tanaman terendah yaitu 117 polong. Meskipun jumlah polong paling sedikit adalah 'anjasmoro', varietas anjasmoro memiliki ukuran biji paling besar sehingga bobot biji per tanamannya pun tidak berbeda dengan varietas Wilis yang memiliki jumlah polong paling banyak.

Adanya perbedaan ukuran biji antar varietas jelas dipengaruhi oleh factor genetic. Ukuran biji memiliki kendali genetik yang besar dan variasinya akan relatif konstan pada lingkungan yang bervariasi (Nusifera, 2000). Terbukti bahwa variasi ukuran biji yang tampak pada penelitian ini sejalan dengan variasi yang terlihat pada deskripsi masingmasing varietas. Deskripsi varietas yang dirilis oleh Departemen Pertanian juga memperlihatkan bahwa varietas Anjasmoro memiliki ukuran biji yang lebih besar dibandingkan varietas lainnya.

Secara keseluruhan, perbedaan masing-masing varietas pada panjang fase reproduktif, jumlah polong total per tanaman, bobot 100 biji dan hasil per petak disebabkan oleh pengaruh komposisi genetik yang dimiliki oleh keempat varietas. Menurut Sitompul dan Guritno (1995), bahwa perbedaan susunan genetik merupakan salah satu faktor penyebab keragaman penampilan tanaman. Program genetik yang akan diekspresikan pada suatu fase pertumbuhan yang berbeda dapat diekspresikan pada berbagai sifat tanaman yang mencakup bentuk dan fungsi tanaman yang menghasilkan keragaman pertumbuhan tanaman. Perbedaan komposisi genetik ini mengakibatkan setiap varietas memiliki ciri dan sifat khusus yang berbeda satu sama lain sehingga akan menunjukkan keragaman penampilan. Menurut Yutono (1985), bahwa setiap spesies/varietas leguminosa berbeda kemampuannya dalam menyerap unsur hara didalam tanah untuk produksi tanaman yang maksimal.

Tanaman kedelai dapat mengikat nitrogen $\left(\mathrm{N}_{2}\right)$ di atmosfer melalui aktivitas bakteri pengikat nitrogen, yaitu Bradyrhizobium japonicum. Bakteri ini terbentuk di dalam akar tanaman yang diberi nama nodul atau bintil akar. Kemampuan memfikasi $\mathrm{N}_{2}$ ini akan bertambah seiring dengan bertambahnya umur tanaman, tetapi akan maksimum pada akhir masa berbunga atau mulai pembentukan biji. Setelah masa pembentukan biji, kemampuan bintil akar memfikasi $\mathrm{N}_{2}$ akan menurun bersamaan dengan semakin banyaknya bintil akar yang tua dan luruh. Di samping itu, juga diduga karena kompetisi fotosintesis antara proses pembentukan biji dengan aktivitas bintil akar (Adisarwanto, 2009). Oleh karena itu disebabkan oleh tingginya kebutuhan $\mathrm{N}$ pada fase ini sementara $\mathrm{N}$ yang diserap dari tanah tidak mencukupi, diperlukan adanya penambahan unsur hara (Lamond \& Wesley 2001). Nitrogen merupakan suatu unsur hara esensial yang dibutuhkan tanaman dalam jumlah banyak, yang berfungsi sebagai penyusun protein dan penyusun enzim (Armiadi, 2009).

Pada tanaman legum, ketersediaan nitrogen bagi tanaman akan menyangkut juga dengan keberadaan nodul akar yang efektif. Terbentuknya nodul akar yang efektif dipengaruhi oleh faktor lingkungan, potensi genotipe untuk membentuk nodul, dan interaksi antara genotipe dan strain bakteri (Nusifera, 2000). Ketersediaan nitrat dalam tanah akan mempengaruhi efektivitas nodul, bahkan nodul tidak akan terbentuk pada kondisi tanah dengan kandungan nitrat tinggi. Konsentrasi nitrat yang relatif kecil diperlukan sebagai starter untuk merangsang pertumbuhan bakteri.

Variabel pengamatan yang secara mandiri dipengaruhi oleh dosis nitrogen adalah, jumlah polong total per tanaman, jumlah polong berisi, dan bobot biji per tanaman. Pemberian pemupukan kedua nitrogen berbeda dosis mampu meningkatkan jumlah polong per tanaman jika dibandingkan dengan tidak diberi. Namun, peningkatan dosis nitrogen tampak tidak lagi meningkatkan jumlah polong per tanaman. Pada sisi lain, peningkatan dosis dari $50 \mathrm{~kg}$ ke $60 \mathrm{~kg}$ memperlihatkan kecenderungan penurunan jumlah polong berisi. Bahkan kecenderungan tersebut 
terlihat nyata pada bobot biji kedelai per tanaman dimana peningkatan dosis dari $50 \mathrm{~kg}$ ke $60 \mathrm{~kg}$ justru menurunkan bobot biji per tanaman. Fakta tersebut menunjukkan bahwa pemberian dosis di atas $50 \mathrm{~kg}$ boleh jadi telah menyebabkan meningkatnya pertumbuhan vegetative atau menyebabkan konsumsi berlebih (luxury consumption). Dengan kata lain, dosis pemupukan nitrogen yang memberikan hasil terbaik pada penelitian ini adalah dosis $50 \mathrm{~kg} \mathrm{~N}$ per hektar.

\section{Kesimpulan}

1. Tidak terdapat perbedaan pengaruh nitrogen pada tiap-tiap varietas yang dievaluasi.

2. Terdapat perbedaan panjang fase reproduktif, jumlah polong total per tanaman, jumlah polong berisi per tanaman, dan bobot 100 biji diantara varietas kedelai. Pada sisi lain, pemupukan nitrogen kedua berbeda dosis memberikan pengaruh yang nyata pada variabel jumlah polong total per tanaman, jumlah polong berisi per tanaman, dan bobot biji per tanaman.

3. Keempat varietas memiliki potensi hasil yang sama jika dikembangkan diwilayah sekitar wilayah penelitian. Namun jika ingin mendapatkan ukuran biji yang lebih besar, varietas anjasmoro sangat direkomendasikan.

4. Dosis terbaik yang dapat meningkatkan hasil antar varietas adalah $\mathrm{n}_{2}(50 \mathrm{~kg} \mathrm{~N} /$ hektar $)$.

\section{Ucapan Terima Kasih}

Rasa terima kasih disampaikan kepada Rektor Universitas Jambi yang telah memberikan bantuan dana penelitian melalui dana DIPA Universitas Jambi Tahun 2014 serta kepada pihak-pihak lain yang telah membantu terlaksananya penelitian ini.

\section{Daftar Pustaka}

Anas I. 1993.Pupuk Hayati (Biofertilizer). Laboratorium Biologi Tanah Fakultas Pertanian IPB. Bogor.

Egli DB, Craft-Brandner SJ. 1996 Soybean. /n Ezamski and A.a. Schaffer (Eds.) Photoassimilate distribution in plants and crops ; Source Sink Relationships. Marcel Dekkor, Inc.
Fitriatin BN, Setiawati MR, Hindersah R. 2001. Pengaruh inokulasi ganda Rhizobium sp. Dan mikoriza terhadap serapan $\mathrm{N}$ dan $\mathrm{P}$ serta hasil tanaman kedelai (Glycine $\max$ ) pada ultisols. Prosiding Seminar Mikoriza, Bandung 23 April 2001.

Hardjowigeno S. 1992. Dasar-Dasar Ilmu Tanah. Akademika Pressindo. Jakarta

Imsande J, Edwards DG. 1988. Decreased rates of nitrat uptake during pod fill by cowpea, green gram, and soybean. Agron. J. 80: 789 - 928.

Manjunath A, Bagyaraj DJ, Gopala Gowda HS. 1984. Dual inoculation with vesicular-arbuscular mycorrhiza and Rhizobium beneficial to leucaena. Plant and Soil 78: 445 - 448.

Myers RH. 1971. Response Surface Methodology. Ally and Bacon, Inc., Boston, MA.

O'gara F, Shanmugam KT. 1978. Mutant strains of clover rhizobium (Rhizobium trifolii) that form nodules on soybean (Glycine max). Cell Biology Vol. 75, No.5 : 2343 - 2347.

Puslitbang Tanaman Pangan, 1993. Deskripsi Varietas Unggul Palawija, Jagung, Sorgum, Kacang-kacangan, dan Ubi-ubian 1912 - 1992. Dikompilasi oleh Husni Kasim dan Djunainah. Bogor.

Sesay A, Shibles R. 1980 Mineral depletion and leaf senescence in soya bean as influenced by foliar nutrient aplication during seed filling. Nn. Rot. 45: $47-55$.

Sprent JI. 1984. Nitrogen fixation. In M.B. Wilkins (Ed.). Advanced Plant Physiology. Longman Singapore Publishers Pte . Ltd., Singapore.

Taiz L, Zeiger E. 1998. Plant Physiology. Sinauer Associates, Inc. Sunderland, United States of America.

Tien HH, Hien TM, Son MT,Herridge D. 2002. Rhizobial inoculation and $\mathrm{N}_{2}$ fixation of soybean and mungbean in the eastern region of south Vietnam. In: D. Herridge. Inoculants and Nitrogen Fixation of Legumes in Vietnam, ACIAR Proceedings 109e.

Xie ZP, Staehelin C, Vierheilig H, Wiemken A, Jabbouri S, Broughton WJ, Vogeli-Lange R, Boller T. 1995. Rhizobial bintilation factors stimulate mycorrhizal colonization of bintilating and nonbintilating soybeans. Plant Physiol, 108: 1519 - 1525. 